\title{
Loïc Wacquant'a İlişkin Notlar Üzerinden Güncel Türkiye Okuması Denemesi
}

\author{
Meriç Kırmızı \\ Ondokuz Mayıs Üniversitesi
}

\begin{abstract}
Öz
Bu makalede Wacquant'ın bir araştırmacı olarak kendine iki görev biçtiği ileri sürülmektedir. Bu görevlerden birincisi, araştırmacılara Bourdieu'yü anlatmak ve Bourdieu'nün kavramsal çerçevesinin akademik araştırmalarda, örneğin kent araştırmalarında, doğru bir biçimde kullanımını desteklemektir. Bu konuda Wacquant'a bir eleştiri, Wacquant Bourdieu'yle ilgili açıklayıcı bilgiler verir ve iyi örneklerin yanında, onun araştırmacılarca sıklıkla yanlış anlaşılıp, kullanıldı ̆̆ı durumları sergilerken, gerçekte kendi Bourdieu okumalarının da bir dolayım olduğu gerçeğini onun göz ardı etmesidir. Wacquant'ın ikinci görevi ise, cezalandırıcı devlet, ırk ve toplumsal sımıflar arasındaki ilişkiler, beden ve kent etnografisi gibi konularda kendi kuramların geliştirirken, yöntembilimsel olarak Bourdieu'nün ayak izinden gitmektir. Bu görevi altında, Wacquant'ın 20. yüzyıl sonuna özgü, iki başh devlet (Centaur state) izleği birçok çalışmasında önemli bir belirleyici olarak yer aldl. Bu devlet tepede özgürlükçü (liberal) ve altta cezalandırtcıydı (paternalist). Bu makale öncelikle, Wacquant'ın bu görevlerini en iyi temsil eden çalışmaların özetler. Ardından, ABD ve Fransa'nın geçen yüzyılın sonlarındaki toplumsal koşullarının Türkiye'deki geçerliliğini tartışır. Son olarak, Bourdieu'nün bürokratik alan gibi kavramsallaştırmalarm Türkiye'deki güncel toplumsal ve siyasal bağlamı anlamaya ne ölçüde rehberlik edebileceğini inceler. Makale, güncel merkezileşme eğilimini devletin cezalandırıcı yüzünün liberal yüzüne ă̆ır basması olarak yorumlar ve bu savı verilerle destekler.
\end{abstract}

Anahtar Kelimeler: Bürokratik alan, iki başlı devlet, cezalandırma, simgesel erk (iktidar), fiziksel mekân 


\title{
Re-thinking Contemporary Turkey with Loïc Wacquant
}

\author{
Meric Kirmizi \\ Ondokuz Mayis University
}

\begin{abstract}
This article argues that Wacquant undertakes two duties in his researches. One of these duties is to explain and promote in academic research, such as urban research the correct usage of Bourdieu's conceptual framework. A trivial criticism to Wacquant in this regard is that he neglects that his own Bourdieu readings are also mediations, even though Wacquant provides explanatory analysis of Bourdieu by showing good and bad examples of applying Bourdieuan concepts. Wacquant's second duty is to follow Bourdieu methodologically in developing his theories on the relationships among the penal state, race and social class, as well as body, and urban ethnography. Under this duty, Wacquant's Centaur state as a two-faced state of neoliberalism emerged as a significant determinant in most of his work. This state was liberal at the top, and paternalist at the bottom. This paper summarizes first, Wacquant's most representative works for these duties. Next, it discusses the applicability of the social conditions of the late twentieth century USA and France for Turkey. Finally, it investigates whether Bourdieuan concepts like bureaucratic field could guide an endeavour to understand the current sociopolitical context in Turkey. The paper interprets the recent power centralization as the domination of state's paternalism over its liberalism, and supports this argument with data.
\end{abstract}

Keywords: Bureaucratic field, centaur state, penalization, symbolic power, physical space 


\section{Giriş}

$\mathrm{Bu}$ çalışma, başlıca çalışma konuları "karşılaştırmalı kentsel aykırılık (marjinallik), etnik ve 1rksal egemenlik, bedenleşme (incarnation), cezalandırıcı devlet" (Wacquant, 2018b) olan Loïc Wacquant'la geç bir 'tanışıklığa' dayanır. Bu tanışıklık ilk olarak, Wacquant'ın soylulaştırma ile ilgili bir makalesi (Wacquant, 2008) ile başladı. Wacquant bu makalesinde kısaca, soylulaştırma araştırmalarının soylulaştırılmasını eleştiriyordu. Wacquant, Slater'ın (2006) eleştirel bakış açısının soylulaştırma araştırmalarından geri çekildiğini, çünkü bu araştırmalarda soylulaştırmanın "yerinden etme" gibi önemli sonuçlarının dikkate alınmayıp, bu kavramın bir bakıma tatlandırıldığını ileri sürdügü̈, bol atıflı makalesine de gönderme yapıyordu. Kendisi Slater'ın eleştirisine, işçi sınıfının hem kamusal alanda, hem toplumsal araştırmalarda görünürlüğünü yitirdiği saptamasını ekliyor ve bu "sınıf körlüğü"ne (Wacquant, 2008, s. 200) karşın, soylulaştırma araştırmalarında eleştirel düşünümselliğin gerekliliğinin altını çiziyordu. Ayrıca, Wacquant devletin soylulaştırmadaki çok yönlü rolünün de dikkate alınmasını önemli buluyordu, çünkü mahalle yükseltmesinin (neighbourhood upgrading) siyasal çerçevesini "yukarıda ekonomik liberalizm, aşağıda cezalandırıcı paternalizm uygulayan, yüzyıl sonunun neo-Darwinci devleti" (Wacquant, 2008, s. 203) oluşturuyordu. Bu soylulaştırma yazınına sıradışı katkısı ile Wacquant, Neil Smith ve Tom Slater gibi bu kentsel olguya politik-ekonomik ve eleştirel yaklaşan araştırmacıların yanında yer almış oluyordu.

Wacquant'in yazarın gündemine (yeniden) girmesine neden olan bir başka şey de, Ondokuz Mayıs Üniversitesi, Sosyoloji Bölümü'nde verdiği Çağdaş Sosyoloji Teorileri dersinin öğrencileriyle birlikte izlediği bir Bourdieu belgeselinde (Frégosi, Gonzalez ve Carles, 2001) Bourdieu'nün sevgili öğrencisi Wacquant'ın da en az iki yerde gösterilmesiydi. İlki, Bourdieu ile birebir yaptıkları danışma toplantısı ki burada Bourdieu'nün karşısında henüz işin başındaki bir doktora öğrencisi varmışçasına, Wacquant'ın oturup, kitaplarını yazmak yerine, oradan oraya gezmesini doğrudan eleştirmesi aralarındaki sıcak usta-çırak ilişkisinin bir göstergesiydi. İkincisinde ise, Wacquant Fransa'daki bir panelde konuşma yaparken görülüyordu. Bu konuşması Wacquant'ın çalışmalarındaki neoliberal iki başlı devlet düşüncesini ve başka önemli düşüncelerini anlamayı sağladığı için, konuşmanın ilgili bölümü aşağıda alıntılanmıştır: 
Eşitsizliklerin ve onların yarattı̆̆ güvensizliğin sosyal devletle iyileştirilmesinden polis ve cezayla iyileştirilmesine bir geçiş, bu. Kabaca söylersek, işçi sınıfının güvencesizleştirilmiş kesimlerinin denetlenmesi, devletin sol elinden, Pierre Bourdieu'nün Dünyanın Sefaleti'ndeki terminolojisini alırsak, yardım eden ve eğiten elinden, konut sağlayan, eğitim ve sağlık hizmeti veren elinden, devletin sağ eline, ceza veren eline, polis, yargıç, gardiyan olan eline geçmiştir. Neoliberal ütopyanın gerçekleştirilmesi, "küçük hükümet" (ya da) devletin eriyip gitmesi anlamina gelmez. (...) Bu liberal-paternalist devletin yükselişi, üst s1nıflar, işverenler için liberal, işçi sınıfları için paternalist, özellikle de yeni hizmet proletaryasının güvencesiz kesimleri için... "Yeni ekonomi" yi başlatan, bugün başımızda olan yeni devletin (gerçek) yüzü budur. (Frégosi, Gonzalez ve Carles, 2001)

Wacquant'ın yukarıda betimlediği, 20. yüzyıl sonuna özgü, iki başlı devlet izleği birçok çalışmasında önemli bir belirleyici olarak yer alır. Birkaç makalesiyle sınırlı olan, bu gecikmiş tanışıklığa dayanarak, Wacquant'ın bir araştırmacı olarak kendine iki görev biçtiği ileri sürülebilir. Bu görevlerden birincisi, toplumbilimcilere Bourdieu'yü anlatmak ve Bourdieu'nün kavramsal çerçevesinin ya da araç gerecinin akademik araştırmalarda, örneğin, kent araştırmalarında doğru bir biçimde kullanımını desteklemektir. İkincisi de, cezalandırıcı devlet, ırk ve toplumsal sinıflar arasındaki ilişkiler, beden ve kent etnografisi gibi uzmanlaştığ konularda kendi kuramlarını geliştirirken, yöntembilimsel olarak Bourdieu'nün ayak izinden gitmektir. Wacquant'la ilgili olumlu bir izlenim olarak, kendini akademik makalelerin klasik yapısı ve diliyle sınırlamayıp, yeri geldiğinde, bir görüşme biçiminde (Wacquant ve Akçaoğlu, 2017) ya da bir bildiri diliyle (Wacquant, 2014) de yayınlar yapmış olmasının altı çizilebilir. Öte yandan, yazılarında anadili İngilizce olmayanlar için sözlük yardımı olmadan okuması güç, oldukça karmaşık ve yetkin bir İngilizce kullandığı bir gerçektir. Wacquant'a önemsiz olabilecek bir eleştiri ise, Wacquant Bourdieu'yle ilgili açıklayıc bilgiler verip, iyi örnekleri göstermesinin yanında, onun araştırmacılarca sıklıkla yanlış anlaşılıp, kullanıldığı durumları sergilerken, Bourdieu'ye çok yakın olmuş ve ondan çok etkilenmiş biri olsa da, gerçekte kendi Bourdieu okumalarının da bir dolayım olduğu gerçeğini göz ardı etmesidir.

Bu yazıda Wacquant'ın iki üstlenilmiş görevini iyi temsil ettiği düşünülen çalışmaları özetlendikten sonra, geçen yüzyılın sonrasından başlayarak, ABD ve Fransa'yı etkilediğini söylediği toplumsal koşulların, 
Türkiye'deki geçerliliği ve Bourdieu ve Wacquant kavramsallaştırmalarının Türkiye'deki güncel durumu anlamak için ne ölçüde yol gösterebileceği veriler üzerinden, kısaca tartışılacaktır.

\section{Wacquant'ın Öncülüğünde Bourdieu'yü İzlemek}

York Üniversitesi'nden Mike Savage'ın düzenlediği bir çalıştaya dayanan "Müdahaleler" (Interventions) başlıklı bir özel sayıya giriş niteliğindeki bir yazısında, Wacquant, Bourdieu'nün çözümleme çerçevesi ile kent sosyolojisi yapmayı destekleme ve örneklendirme amacı gözetir. Öncesindeki çalıştayın gündemine göre, yüzyılın başında bir yanda hızlı teknolojik ve ekonomik yeniliklerin mekânı olan kentin, öte yanda toplumsal eşitsizliklerin, kemikleşmiş aykırılığın ve kültürel bölünmelerin de gözlemlendiği bir alan olarak incelenmesinde ve böylece, kent sosyolojisinin zenginleştirilmesinde Bourdieu keşfedilmemiş bir hazine gibidir (Wacquant, 2018a, s. 91).

Savage (2012) kent sosyolojisinin kuramsal ve görgül çalışmalar bölünmesiyle ilgili açmazını, Bourdieu'nün saha çözümlemeleri geleneğini, güncel kentsel uzamın akışlarını ve hareketliliğini, yersizyurtsuzlaştırma ve yeniden mekânsallaştırma (re-territorialization) süreçlerini incelemek için benimseyerek, aşmayı önerir. Ustasının kent sosyolojisi açısından değerine inanan Wacquant da Bourdieu'nün çözümleme çerçevesinin değerinin altını çizer. Bourdieu'nün çerçevesi ilk olarak, büyük erk yap1larını, kurumların orta düzeyini ve günlük etkileşimlerin ufak ayrıntılarını ilişkilendirdiği, yani farklı çözümleme düzeylerinde çalışmaya olanak sağladığı için değerlidir. Bunun yanında, toplumsal yaşamın iki kurucu bileşeni olan maddi ve simgesel belirleyicileri kapsaması bakımından önemlidir. Son olarak, Bourdieu'nün çerçevesinin Wacquant'ın deyişiyle, "yöntembilimsel çoktanrıcılık" (Wacquant, 2018a, s. 92) niteliği vardır; niteliksel olarak tabandaki kentin toplumsallığının ve kültürünün incelemesine ve niceliksel olarak küresel ölçekte bir kentçilik anlayışına (global urbanism) izin verir. Wacquant'a göre, bunlardan ilkine yönelik olan saha araştırması, "ötekinin ayrıntılı bilgisi (intimate knowledge) üzerinden kendini bilmenin etkili aracı" (Wacquant, 2004, s. 403) olarak Bourdieu'nün bilimsel uygulamaları için vazgeçilmezdir.

"Bourdieu Comes to Town" adlı makalesinde, Wacquant (2018a) ilk olarak, Bourdieu'nün Cezayir'in ve Fransa'da kendisinin doğduğu köy 
olan Béarn'ın kentleşme ile birlikte gelen toplumsal dönüşümünü çözümlediği, 1960'ların başındaki erken dönem çalışmalarının bir incelemesini yapar. Aynı çabayı, daha erken tarihli başka bir makalesinde de Bourdieu'nün antropolojisini, kavramsal araçlarını nasıl Kabiliye'nin ve Béarn'ın karşılaştırmalı saha çalışmalarından ürettiğini, fotoğrafın erken dönem etnografik çalışmalarındaki önemini öğretmek için gösterir (Wacquant, 2004). "Bourdieu Comes to Town" da Wacquant (2018a) ikinci olarak, Bourdieu'nün etkilendiği yazarlar üzerinden çalışmalarının başlıca yöntembilimsel ilkelerini paylaşır. Makalenin son bölümünde de, İsrail, Fransa, ABD ve Portekiz'den Bourdieu'yü örnek almış, iyi kent çalışması örneklerinin bir derlemesini ve değerlendirmesini yapar.

Bu örnekler üzerinde burada çok durulmasa da, Wacquant'ın kentbilimcilerin bugüne dek kent yöneticilerine az 'sorun' çıaran, varlıklı, güçlü ve ayrıcalıklı mahalleleri, "alt toplumsal kategorilere ve alanlara olan romantik düşkünlükleri" (Wacquant, 2018a, s. 101) nedeniyle, görmezden gelmiş olmaları saptaması dikkate değerdir. Wacquant özellikle genç kent araştırmacılarına Bourdieu'nün kavramlarını kullanırken dikkat etmeleri, daha doğrusu yapmaktan kaçınmaları gereken şeyler konusunda birkaç önemli uyarıda da bulunur. Bunlar, "kavramların fetişleştirilmesi (çalışmayı daha başlamadan bitirir), moda (langue du jour) olduğu için, 'Bourdieuce konuşmanın' çekiciliği ve kuramsal çerçevesinin zorlama bir biçimde blok olarak dayatılması"dır (Wacquant, 2018a, s. 98).

Wacquant Bourdieu'yü kent araştırmalarında kullanacaklara yönelik uyarılarını makalenin içinde biraz daha açar. İlk uyarısı, Bourdieu'yü yalnızca bir kuramciya indirgeyip, kuramlarının arkasında yatan, derin saha araştırmalarını dikkate almamakla ilgilidir. Oysaki Bourdieu "'gösterişçi kuramlaştırma'nın şiddetli bir eleştirmeni"ydi (Wacquant, 2018a, s. 100). İkinci uyarı söylem tuzağına düşmemek için yapılmıştır, çünkü Bourdieu'nün kavramlarına başvuran birçok çalışmada "sözler vardır, ama kavramlar yoktur" (Wacquant, 2018a, s. 100). Böyle çalışmalarda Bourdieu'nün kavramlarının içleri boşaltılır ve söylem (retorik) çözümlemenin önüne geçer. Bunun sonucunda, Bourdieu'nün kavramları örneğin, "habitus" kavramında olduğu gibi sulandırılır ve Wacquant'ın biraz da alaycılıkla söylediği gibi her şeye habitus denilmeye başlanır: anakent habitusu, banliyö habitusu, soylulaştırma habitusu gibi. Wacquant'ın son uyarısı da Bourdieu'nün kavramlarını, yani “habitus, sermaye, toplumsal uzam, alan, doxa, simgesel erk ve düşünümsellik" $i$ (Wacquant, 2018a, s. 104) blok olarak bir arada kullanmak yerine, daha etkili ve doğ- 
ru bir yöntem olarak bir araştırmada yalnızca bir kavrama odaklanmaktır. Hatta Wacquant Bourdieu'nün bütün kavramları içinde bir önem siralaması olduğunu varsayarak, "toplumsal uzam" kavramının bir ana kategori olarak içlerinden en güçlüsü ve en üretkeni olduğu değerlendirmesini yapar (Wacquant, 2018a, s. 101).

Wacquant'a (2018a) göre, Bourdieu'nün araştırma ilkelerinden birincisi Bachelard'in tarihsel bilgibilimine dayanarak, siyasal söylemleri örneğin, kent siyaseti ile ilgili olanları olduğu gibi kabul etmemeyi ve en başta doğru soruları sorabilmeyi içerir. İkinci ve Weber'in yaklaşımını andıran ilkesi, toplumsal yaşama sinen yalnızca ekonomik egemenlik olmadığ 1 için, toplumsal araştırmada öznenin, öznenin dünyasının ve bunları inceleyen çözümleyicinin üçlü tarihselleştirilmesine ilişkindir. Bu yaklaşıma göre kentsel uygulamalar, "çoklu zamansallıklar üzerinden verilmiş savaşımların ürünleri, silahları ve çkarları" (Wacquant, 2018a, s. 98-99) olarak ele alınmalıdır. Leibniz ve Durkheim'ın ağırlığı olan üçüncü ilkede simgesel uzam (symbolic space), toplumsal uzam (social space) ve fiziksel mekân (physical space) arasındaki karşılıklı ilişkileri topolojik (birbirlerine göre bağıl konumlarını gözeterek) bir akıl yürütme ile izlemek gerektiği vurgulanır. Toplumsal bölünme ve ayrımlar fiziksel mekâna somut ve simgesel olarak yansıdığı ölçüde fiziksel mekân somutlaştırılmış toplumsal uzamdır (Wacquant, 2018a, s. 99). Cassier'den esinlenmiş dördüncü ilkede de simgesel yapıların toplumsal eğilimler ve konumları belirlemedeki önemine değinilir. Burada Wacquant Bourdieu'nün sıkça göz ardı edilen "simgesel erk"1 kavramının altını çizer. Buna göre, öznelerin dünyayı anlamlandırmakta kullandıkları simgesel sınıflandırmalar birbirleriyle yarışma içindedirler ve bu yarışma kentin fiziksel ve simgesel mekânını örneğin, kentteki yapıları, etkinlikleri ve yer adlarını etkiler. Bu simgesel güçlerin kentsel alan üzerinden çatışması Türkiye'de de yaygın olarak gözlemlenen ve çalışılan bir durumdur.

Makalenin sonunda, Wacquant Bourdieu'nün "kentsel olanı açık sermaye biçimlerinin birikim, farklılaşma ve yarışma sahası olarak yeniden kavramsallaştırmasının" (Wacquant, 2018a, s. 104) kenti tarihsel savaşımların merkezi konumuna getirdiğini belirterek bitirir.

\footnotetext{
${ }^{1}$ Bourdieu ile ilgili Türkçe yazında sıklıkla "simgesel iktidar" olarak Türkçeleştirilmektedir.
} 


\section{Wacquant'ın Bourdieu Destekli Kent Kuramı: “Kentsel Prekarya- nın Ölüm Üçgeni" ${ }^{2}$}

Wacquant'ın kendi çalışmalarındaki vazgeçilmez bir izlek de "mülksüzleștirilmiş ve onursuzlaştırılmış nüfusları hedef alan, en başta da ceza ile ilgili kolu (polis, mahkemeler, tutukevi, çocuk cezaevi ve uzantıları) gibi değişik öğeleriyle devletin dönüşümü"dür (Wacquant, 2014, s. 1690). Wacquant'ın birçok çalışmasında ve konuşmasında dile getirdiği önemli savlarından biri 20. yüzyıl sonlarından başlayarak devletin kazandığı iki başlı niteliktir. Bu iki başlı devlet tepede özgürlükçü ve altta cezalandırıcıdır; bu durum demokrasi ülküsüyle çelişir. Bu görüşün kalıtı büyük olasılıkla kendisine hocası Bourdieu'den geçmiştir. Bourdieu (2015) Dünyanın Sefaleti'nde devletin 'ikiyüzlülügüüü' ya da çifte standardını devletin eril ve dişil alanları olarak sınıflandırır. Devletin eril alanları neoliberal ekonomi ve politika yönetimi ile ilgili alanları içerirken, dişil alanları eğitim, sağlık gibi kadınların ağırlıkta olduğu ve kadınların kamusal yaşamın içinde sıklıkla görünebildiği alanlardır. Öyle ki kadınların çıkarları sosyal devletle örtüştüğü için, Bourdieu kadın hareketine "politik hat" olarak devleti savunmayı önerir (Frégosi, Gonzalez ve Carles, 2001).

Wacquant ise, liberalizmin bir ara farklı toplumsal alanlarda birçok alıcısı çıkan (ulus) devletin küçüldüğü, gerilediği, hatta yok olduğu varsayımını karşısına alıp, ustalıkla çürütür. Bu liberal varsayım yalnızca bir parça doğrudur, çünkü evet, sosyal devlet, yani çalışma yaşamında çalışanların haklarını koruyan devlet ya da "devletin sol eli" piyasa karş1sında küçülmüş ve sorumluluklarını piyasaya devretmiştir. Öte yandan, liberal-paternalist devletin polis gücü büyümüş, "devletin sağ eli" güçlenmiş ve özellikle, güvencesiz çalışanların (prekaryanın) özgürlükleri artarak yok edilmiştir. Wacquant'a göre "yeni ekonomi" ya da yoksullu$\breve{g u}$ cezalandırıcı yönetimin suç ve güvenlikle ilgili yeni söylemleri devletin iki başlı olmasıyla ilgili dönüşümün önemli göstergeleridir (Frégosi, Gonzalez ve Carles, 2001).

Wacquant (2014) kendi kitapları olan Kent Paryaları ve henüz Türkçeye çevrilmemiş olan Punishing the Poor (Yoksulu Cezalandırmak?) ve

\footnotetext{
${ }^{2}$ Wacquant'ın makalesinin birinci şeklinin alt başlığı olan “The 'fatal triangle' of the urban precariat" in (Wacquant, 2014, s. 1692) çevirisidir.
} 
Deadly Symbiosis (Ölümcül Ortak Yaşam?) adlı eserlerinin bir üçlemenin parçası olduğunu belirtir. Bu kitapların "kentsel dönüşüm üçgenini, (üçgenin) köşelerini oluşturan sınıf, etnik köken ve devlete göre sorguladığını ve neoliberalizmin düzgün bir toplumbilimsel yeniden kavramsallaştırmasının yolunu döşediğini" (Wacquant, 2014, s. 1690) dile getirir. $\mathrm{Bu}$ hedefine yönelik olarak Bourdieu'nün toplumsal uzam, bürokratik alan ve simgesel erk kavramlarına anlamını netleştirmek istediği "getto" gibi tanımlamaları ekler ve neoliberalizm canavarının (the neoliberal Leviathan) cezalandırarak yönettiği "kent prekaryası"nın oluşumunu araştırmaya koyulur. Bu üçleme ile katkısının yoksulluğun düzenlenmesinin bozulumunun ve sanayi-sonrası dönemin güvencesiz çalışanlarının oluşumunun karşılaştırmalı bir toplumbilimini ve böylece, neoliberal canavarın tarihsel antropolojisini yapmak olduğunu söyler (Wacquant, 2014, s. 1691). Ona göre neoliberalizmin cezalandırıcı toplumsal politika (workfare) ve ceza sisteminin genişletilmesi (prisonfare) gibi belli başl kurumsal araçları vardır. Bunlar arasında bir kültürel yapıştırıcı işlevini gören şeyse, liberalizmin kişisel sorumluluk öğretisidir.

Kent Paryaları kitabının konusu olan siyah Amerikan gettosunun birdenbire içe patlamasını Wacquant Harvey'nin (1989) 1970 sonrasında yönetimsel kentlerden girişimci kentlere doğru bir değişim olduğu düşüncesi ile ilişkilendirerek açıklar. ABD'deki yoksul mahallelerin "hipergettolaşması"nın İkinci Dünya Savaşı sonrasına dek uzanan, emek piyasasındaki ${ }^{3}$ ve kentsel alandaki bölünmeler, sosyal devlet anlayışındaki gerilemeler ve bunun sonucunda "kara kuşak"ta ${ }^{4}$ yoksulluğun artması ve desteksiz kalmasıyla ilgili olan siyasi ve ekonomik köklerine bakar (Wacquant, 2015, s. 84-85). Kentin yönetim anlayışındaki ve buna eşlik eden değişimler Wacquant'a göre, siyah Amerikan gettosunda da belirleyici bir dönüşüme, hatta çözülmeye yol açar. 1960'ların sonlarına dek toplumsal ya da ortaklaşa (communal) nitelikler taşıyan getto sanayisiz-

\footnotetext{
${ }^{3}$ Emek piyasasındaki kötüleşme ve güvencesiz çalışanların oluşumu ne ABD'ye, ne Fransa'ya özgü bir durumdur. Diğer Avrupa devletlerindeki güvencesizleştirme, artan yoksulluk ve bunlara yönelik olan sosyal politikalarla ilgili İstanbul'daki yakın tarihli bir uluslararası toplantının yabancı katılımcılarıyla bir söyleşi için bkz. Şahin, 2019.

${ }^{4}$ Wacquant "kara kuşak" deyişini ABD'deki "metropol merkezlerinde Afrika kökenli Amerikalıların yaşadığı yoksul semtleri" (Wacquant, 2015, s. 187) belirtmek için kullanır. Aynı sanayisizleşme süreçlerinden etkilenmiş olan "kızıl kuşak" ise, "Fransız işçi sınıfı banliyösü"nü (Wacquant, 2015, s. 188) tanımlar. Her iki alan da kendi ülkelerine özgü koşullar içinde kent paryalarını barındırır.
} 
leşmenin de etkisiyle parçalanır ve hiper-gettoya ya da daha ötesine, "getto-karşıtı"na (anti-ghetto) dönüşür. Wacquant 1990 sonrası hipergettolarının iki belirgin özelliği olarak merkezsizleşmeleri ya da farklılaşıp, bölünmeleri ve gettonun merkezindeki yoğun çürümeyi gösterir (Wacquant, 2015, s. 67). Sanayi sonrasının güvencesiz çalışanlarının oluşumu ve bunda devletin rolü ile ilişkili olan aynı süreç hem ABD'de, hem de Avrupa kentlerinde görülür ve yeni bir yoksulluğu yönetme biçiminin doğması ile sonuçlanır (Wacquant, 2014, s. 1692). Bu nedenle, Wacquant kent sosyolojisi çalışmalarına ivedilikle hükümetin ve politikalarının yeniden eklenmesi gerektiğini savunur.

Devletler kent paryaları ile başa çıkmak için yoksulları ya yalıtılmış ve etiketlenmiş mahallerinde ya da "cezaevlerinde cezai önlemlerle tutarak yoksulluğu suç haline getirmektedir," (Wacquant, 2015, s. 303). Wacquant Punishing the Poor'da sinıfsal dönüşüm ve devletin yeniden yapılandırılması arasındaki iki yönlü ilişkiyi detaylı olarak ele alır. Örneğin, ABD'de yeni yoksulluk biçimini yönetmek için kentsel aykırılığ 1 yeni yönetme politikasını ve kısıtlı toplumsal politikayı birleştirirler. Bu kitaptaki savlar üç kırılma ya da değişim üzerinden gerçekleşir: suç ve ceza arasındaki ayrılma; ceza politikası ve toplumsal politika arasındaki bütünleşme ya da aynılaşma ve ceza adaletine yönelik ekonomik ve kültürel yaklaşımlar arasındaki buluşma. Wacquant bu türden gelişmelere dayanarak kentsel aykırılığ 1 yönetmenin siyasal tekniği olarak cezalandırma modelini geliştirir. Disiplin, denetim ve neoliberalizmle ilgili kendisininkine yakın çalışmalar yapan Foucault, Garland, Harvey gibi kişilerden Wacquant'ın ayrıldığı nokta, onun devletin ceza ile ilgili kolunu neoliberalizmin merkezi bir bileşeni olarak yorumlamasında yatar. Bütün bu gelişmelerin sonucunda haklı olmayan bir "yasa ve düzen pornografisi" (Wacquant, 2014, s. 1695) ortaya çıkar.

Wacquant'ın üçlemenin son kitabı olan Deadly Symbiosis'de yapmaya çalıştığ şey ise, ırk ve kamusal erk arasındaki çağdaş ilişkinin bir incelemesidir. Bu kitabın başlıca savı ırk ve etnik kökenin cezalandırmayı kolaylaştırıp, yoğunlaştırdığıdır. ABD'de ceza devletinin yükselmesiyle birlikte siyah olmak neredeyse tehlikeli bir sapkınlık olarak görülmeye başlanmıştır. Wacquant 1973'ten başlayarak alt sınıftan siyahların cezaevine kapatılmasında büyük bir artış olduğu saptar. Bunun gerisinde, bir "etnik kap olarak gettonun çöküşü ve bunu izleyen, gettonun kalıntılarının içinde ve çevresinde ceza ağının yayılması" (Wacquant, 2014, s. 1696) olarak tanımladığı toplumsal gelişmeler yatar. ABD'de görülen bu ırkın 
suçlulaştırılması ya da "gettonun cezaevileştirilmesi" ve suçun ırksallaştırılması ya da "cezaevinin gettolaşması" durumlarına karşılık Avrupa Birliği'nde göçmenlerin sıklıkla tutuklanması söz konusudur. ABD ve $\mathrm{AB}^{\prime}$ deki birbirini andıran gelişmeleri Wacquant şöyle özetler: "ileri ayk1rılıkla ${ }^{5}$ ilişkilendirilen kentsel türbülansların cezalandırılması, ırksallaştırılması ve apolitikleştirilmesi" (Wacquant, 2014, s. 1696-1697). Artık bu türden gelişmeler, Güney Amerika'da örneğin, Brezilya'da da yoksulluğun askerileştirilmesi ya da yoksul mahalle yaşayanlarına "ulus düşmanları" (Wacquant, 2014, s. 1697) gözüyle bakılması olarak karşımıza çıkar. Burada önemli olan soru şudur: cezalandırma yöneyi (vektörü) kimleri vurmaktadır? İşte, cezalandırmanın yapısal bir ayrımcılık uyguladığ1 savı Deadly Symbiosis' in ana düşüncesini oluşturur.

Wacquant neoliberalizm çağında sınıfın yeniden yapılandırılması, etnik-1rksal bölünme ve devletin işleyişi (state-crafting) arasındaki bağlantılarla ilgili önemli kuramsal katkısını geliştirmek için ağırlıklı olarak Bourdieu'den ödünç aldığı simgesel erk, bürokratik alan, toplumsal uzam ve habitus gibi kavramlardan yararlanmıştır. Simgesel erk kavramını kamu politikalarının resmi sınıflandırmalar ve kategorileştirmeler yoluyla kentsel gerçekliği yaratmaya katkıda bulundukları gerçeğini açığa çıkarmakta kullanır (Wacquant, 2014, s. 1697). Bürokratik alanı kamu mallarının dağıtımına odaklanıp, toplumsal politikaları ve ceza politikalarını ilişkilendirmek ve devletin içindeki koruyucu ve disipline edici kutupların çatışmasının bir ürünü olan bu politikaların bütünleştiğini göstermek için kullanır (Wacquant, 2014, s. 1698). Toplumsal uzam kültürel ve ekonomik sermaye gibi verimli kaynakların dağıtımın haritalandırılmasını sağlar ve kentsel hiyerarşinin farklı düzeylerindeki yaşam olanaklarını belirler.

Habitus ise, aykırılık, ırksallaştırma ve tutuklamanın getirdiği bedensel kısıtlamaları ve daha soyut olarak da "toplumsal yapıların nasıl yaşanmış gerçeklere yeniden çevrildiğini" (Wacquant, 2014, s. 1699) anlamaya yarar. Ancak, Wacquant'a göre işin içinde devlet olmadan kentsel etnik, rrksal ve sınıfsal hiyerarşileri anlamak olanaksızdır. Bu kavramlara göre yapılandırdığı kuramsal üçgenini "bölgesel damgalama" (territorial stigmatization), ileri aykırılık, cezalandırıc çevreleme (punitive containment), aşırı tutukla-

\footnotetext{
${ }^{5}$ Mehmet Doğan bu terimi Kent Paryaları'nda "ileri marjinallik" olarak çevirmiştir. Bu eserin sekizinci bölümünde Wacquant "ileri marjinalliğin" altı ayırıcı özelliğini açıklar (Wacquant, 2015).
} 
ma (hyper-incarceration), olumsuz toplumsal meşrulaştırma (negative sociodicy) gibi kendi geliştirdiği kavramlarıla derinleştirir.

Wacquant'a göre ceza adaleti ya da yargilaması toplumun alt katmanlarındaki güvencesiz çalışanların şansızlığını haklı kılarken, toplumun üst katmanlarındaki egemenler ise, seçkin eğitim kurumlarının dağıttığ diploma gibi araçlarla değerlerine değer katmakta ve şanslılıkları toplumsal kabul görmektedir. Bu nedenle, "Irksal kategorileştirme ve yasal yaptırım devletin kovduklarını (state outcasts) üretir" (Wacquant, 2014, s. 1702), çünkü rrksal etiketleme (racial branding) ve yasal cezalandırma devlet kaynaklı bir onursuzlaştırmaya ya da karalamaya yol açar. Wacquant ABD'deki ve Fransa'daki ortamın tarihsel ve karşılaştırmalı bir çözümlemesi üzerinden devletin aykırılık üretimindeki önemli rolüyle ilgili saptamasını yinelerken, tarihte de yoksul yardımı ile ceza amaçlı kapatma arasında işlevsel bütünleyici bir ilişkinin olduğunu belirtir. Prisons of Poverty adlı başka bir çalışmasında yaptığı şey de "kutuplaşan kentte yoksulluğu cezalandırmaya önayak olan polis stratejisinin ve 'sıfır hoşgörü' değişmecesinin bütün gezegene yayılmasını" (Wacquant, 2014, s. 1703) kayda geçmektir.

Geniş kapsamlı bir bildiriyi ya da kamu dersini andıran bu konuşmasına Wacquant toplantıyı ilgilendiren üç izlek ile başlar: kentteki sınıfsal bölünmeler; etnik ayrımların dayanakları, biçimleri, olası sonuçları ve ceza yargılaması ya da ceza adaleti. Wacquant kendisinin de ilgilendiği bu konuları tek tek ele almanın eksiklikler doğuracağını düşünür. $\mathrm{Bu}$ nedenle, sınıfsal yeniden yapılandırmanın bir sonucu olarak kentsel sürgünü (urban relegation), etnik kökenin yansımalarını ve ceza devletini çalışanların bir diyalog içine girmesi gerektiğini ileri sürer. Aynı zamanda, disiplinler arası çalışmaları da önerir örneğin, kent sosyolojisi ve ekonomik çözümlemeler ya da suç bilimi ve toplumsal çalışma ve bunlar1 çapraz kesen coğrafya gibi. Wacquant'ın bir diğer önerisi ise, sosyal devletin büyük ölçüde yeniden yapılandırılmasıdır (Wacquant, 2015, s. 306). Wacquant bütün bu etnisite, suç, vb. konuların diğer ucunda ise, "iki başlı devlet"in olduğunu söyler. Makalesini neoliberalizm ve cezac1lık (penality) arasındaki yakın ilişkiyi bir kere daha vurgulayarak ve araştırmacılara yaptığı şu, tanıdık çağrıyla bitirir: "kent aykırılı̆̆ının, etnik kökenin ve cezacılığın araştırmacıları birleşin. Entelektüel zincirlerinizden başka yitirecek bir şeyiniz yok" (Wacquant, 2014, s. 1704). 


\section{Bourdieu'de ve Wacquant'ta Devlet Algisı}

Wacquant Bourdieu ile ilgili bir söyleşisinde Bourdieu'nün devleti nasıl algıladığını simgesel erk ve bürokratik alan kavramlarına göndermeler yaparak açıklar. Devlet kavramını düşünürken insanların düştüğü genel yanılgılar devleti soyut ve öznesi belirsiz, ama aynı zamanda tek ve değişmez bir bütün olarak düşünmektir. Wacquant Bourdieu'nün devlet algısı ile ilgili şöyle der:

Bourdieu, devletin çapının, sınırlarının, görevlerinin, aldığı şeklin tarih boyunca değişime uğradığını söyler. (...) Yekpare devlet algısını değiştirmeliyiz, yerine tanımlamaları ve kamuya ait malların dağıtımını tekeline alan kurumlar olarak bürokratik saha kavramını koymalıyı. (...) Bu sayede, devletin çok heterojen ve parçalanmış olabileceğini de, ya da çok merkezî, birleşik ve tutarlı olabileceğini de görmüş oluruz. Kamusal malları tanımlayan ve dağııımını gerçekleştiren bürokrasilerden oluşan bir mücadele sahasıdır devlet, ancak neyin kamusal mal, neyin kamu bürokrasisi olduğu konusunda da sürekli bir çatışma vardır (Bozçalı, Aydın, Özden ve Wacquant, 2007).

Wacquant ve Bourdieu devleti belirli tarihsel koşullarda maddi ve simgesel erki elinde bulunduran bir kurumlar bütünü ya da bürokratik alan olarak görürler. Maddi erk kamusal malların, kaynakların dağıtımıla ilgiliyken, simgesel erk yönetimin insanların anlıksal kategorilerini biçimlendirme yetisinin bir sonucudur. Wacquant güç odaklarındaki çeşitlenmeyi moderniteye ve kapitalizme geçişle birlikte gelen kurumsallaşma ile ilişkilendirir: “(...) üniversiteler sembolik iktidarın özerk bir merkezi olarak ortaya çıkmıştır. Hukuk ayrı bir kurum olarak belirmiştir. Ekonomi din, kan bağı ve devletle olan bağlarını koparıp özerkleşmiştir, modern bürokratik devletin kendisi ortaya çıkmıştır. (...) Bu farklı sermaye biçimlerinin hiyerarşisi nasıl belirlenir?" (Bozçalı, Aydın, Özden ve Wacquant, 2007) Bu kurumsallaşma nedeniyle modern bürokratik devlet aynı zamanda, farklı güç odaklarının kendi maddi ve simgesel çıkarları için bir savaşım alanıdır. Wacquant bu savaşımın Bourdieu'ye göre devlet ve ona bağımlı olanlar arasındaki bir çatışmadan çok, devletin egemenleri arasındaki bir çatışma olduğunun altını çizer. 


\section{Wacquant'la bir Güncel Türkiye Okuması Denemesi}

Güncel Türkiye'deki siyasal ya da bürokratik alanı Bourdieu ve Wacquant'ın kavramlarına başvurarak okumak olanaklıdır. Söz konusu dönemin koşullarında elinde maddi ve simgesel erki toplamış, ama yine de iç çekişmeleri olan çoklu bir yapı olarak devletin Türkiye'deki güncel karşılığını kolaylıkla düşünebiliriz. Üst yönetim ve uzantıları kamusal kaynakların kullanımını, hangi kuruma ne kadar kullandırılacağını, hangi alanları piyasaya bırakıp, özelleştireceğini, vb. yüksek oranda belirler. Ek olarak, Wacquant'ın ABD için saptadığı toplumsal politikalar ve ceza politikaları arasındaki örtüşmenin izi Orta Doğu coğrafyasında da sürülebilir. Yine, simgesel erk çekişmeleri de toplumsal olarak gitgide kutuplaştığı birçok kamuoyu araştırmasıyla (örneğin, bkz. Erdoğan, 2018) saptanmış olan Türkiye'de oldukça belirgin bir durumdur. Bu toplumsal bölünme toplumsal bütünleşmenin dayanağı olması beklenen başlıca kültürel sermaye öğesi olarak dile ve onun gündelik kullanımına bile örneğin, selamlaşma biçimlerine (Akçaoğlu, 2018, s. 96) yansır.

Güncel Türkiye'de de simgesel uzam, toplumsal kutuplaşmanın ya da "sembolik kutuplaşma"nın (Akçaoğlu, 2018, s. 158) ayırt edici bir yönünü oluşturduğu toplumsal uzam ve fiziksel mekân arasında güçlü ilişkiler söz konusudur. Simgesel erk toplumsal uzamı da etkileyerek fiziksel mekânı büyük ölçüde dönüştürür; dönüştüremediği yerleri etiketler (Kılıç ve Kaya, 2018) ya da çeşitli politikalarla kuşatır. Örneğin, İstanbul'da Taksim Meydanı'nda ayrı simgesel güçleri ve onların ideolojilerini temsil eden kamu yapıları olarak Atatürk Kültür Merkezi (AKM) yıkılırken, karşısına büyük bir cami yapılır (bkz. Şekil 1 ve 2); bu simgesel çatışma fiziksel mekânın dönüşümü öncesinde söylemsel tartışmalarda da görülür (Şahin, 2017). Kentteki bu simgesel çatışmayı toplumsal uzamın tarihsel bir öğesi olarak düşünülebilecek olan ortak bellek ve fiziksel mekân ilişkisi ile bağlantılı olarak değerlendiren farklı bakış açıları da vardır (Bayhan, 2013). Fiziksel mekân üzerinden yaşanan simgesel güç çatışmalarının Türkiye örnekleri "mega proje"lere konu olan yeni kamusal alanların adlarıyla ilgili tartışmalar ya da sonradan değiştirilen yeraltı treni durağı, meydan ve sokak adları, vb. olarak çoğaltılabilir. 


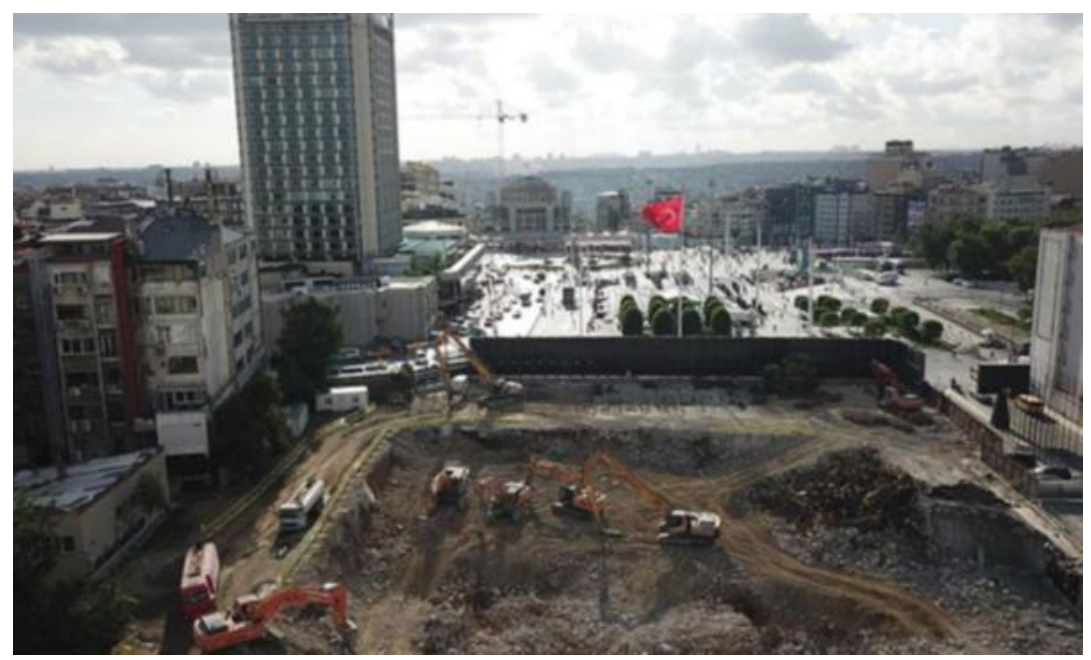

Şekil 1. Yıkılmış AKM ve Yapımı Süren Cami ile Taksim Meydanı (Kaynak: http://www.cumhuriyet.com.tr/haber/turkiye/986436/AKM_nin_yikimi_tamaml andi.html)

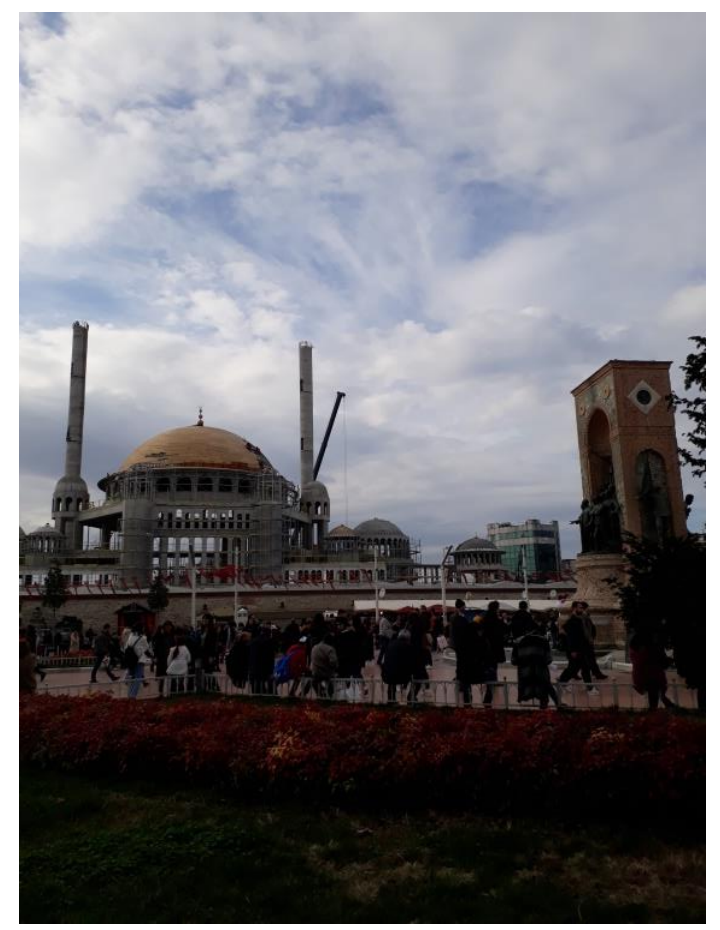

Şekil 2. Yapımı Süren Taksim Camisi ve Taksim Cumhuriyet Anıtı (Kaynak: kişisel arşiv) 
Wacquant'ın neoliberalizmin iki başlı devlet düşüncesini, yani yukarıda liberal, aşağıda cezalandırıcı devletini Türkiye'deki güncel duruma uygulamak ise, biraz daha güç gerektiren bir çabadır. Bunun nedeni, günümüz siyasal konjonktüründe zaten herkese eşit davranan demokratik bir yönetim yapısı ülküsüne çoktan ulaşılması değil, ama günden güne güç odaklarının tek bir kurumda toplanmasıyla birlikte modern bürokratik alanın özerk kurumlardan oluşan çoklu yapısından uzaklaşılmasından kaynaklanır. Bu güncel merkezileşme eğilimi ki Wacquant söyleşinde bunun olasılığını yadsımaz (Bozçalı, Aydın, Özden ve Wacquant, 2007) Wacquant'ın kavramlarıyla söylenirse, devletin aşağıya gösterdiği cezalandırıcı yüzünün, yukarıya gösterdiği “bırakınız yapsınlar"cı yüzüne ağır basması olarak tanımlanabilir. Aynı zamanda Türkiye'deki yönetimsel paternalizm, toplumsal kutuplaşmadan beslense de kendi simgesel erkini ve gerisindeki simgesel şiddeti kabul etmeyen toplumun bütün kesimleri için eş derecede cezalandırıcı olması bakımından Wacquant'ın incelediği ABD'deki siyah ve Avrupa'daki göçmen gettolarındaki durumdan daha geniş kapsamlıdır.

Wacquant kendi çalışmalarında bu yeni devletin ve onun yeni ekonomisinin cezalandırma yöneyinin en çok kimleri vurduğuyla ilgili yapısal bir ayrımcılık olduğu savını geliştirir. Güncel Türkiye'deki cezalandırma yöneyi ise, ABD'deki ya da Fransa'daki gibi tek bir etnik, ırksal ya da toplumsal sınıfa odaklanmaz; kendisine karşı gelen herkese yöneliktir. Neredeyse kent değil, ülke ölçeğinde bir hipergettolaşma söz konusudur. Özetle, neoliberalizm ve cezalandırma ilişkisi bu coğrafi bağlamda da kalıcıdır, ama niteliği ve niceliği herhangi bir Batı ülkesinden farkl1dır. Bunun bir göstergesi artan tutuklu sayısını karşılayabilmek için cezaevi yapımındaki artışlardır. İlk aşamada cezaevi yapımı yasal bir düzenleme ile kolaylaştırılmıştır (Toker, 2017). Bundan sonra 2017'de Türkiye'nin çeşitli yerlerinde $4.115 .558 \mathrm{~m}^{2}$ lik cezaevi yapım işi ihalesi yapılmış, bunlardan 2.269.924 $\mathrm{m}^{2}$ sinin projesi $2017^{\prime}$ de bitirilmiştir. Ayrıca toplamda $809.584 \mathrm{~m}^{2}$ lik cezaevinin yapımı da bitirilmiştir.

Resmi bir rapora göre “(...) 2017 yılında şehir yerleşim merkezi içinde kalan, gerekli eğitim ve iyileştirme çalışması yapılamayan ve fiziki olarak da ekonomik ömrünü dolduran 31 ilçe ceza infaz kurumunun kapatılması planlanmış ancak hükümlü ve tutuklu sayısındaki yoğunluk nedeniyle 10 kurum kapatılmıştır," (T.C. Adalet Bakanlığı Strateji Geliştirme Başkanlığı, 2018a, s. 60). Yatırım projeleri listelerinde 2017 yılından sonraya kalan 23 cezaevinin toplam proje tutarı 4.120.000.000TL iken, 
2018 'de bu tutar $46(26+20)$ cezaevi için yaklaşık iki kat artışla 9.021.500.000TL olarak yenilenmiştir. 2016 yılının toplulaştırılmış yatırım projeleri listesinde aynı cezaevi kalemi görülmemektedir (T.C. Adalet Bakanlığ1 Strateji Geliştirme Başkanlığı, 2016, 2017, 2018b). Cezalandırmanın bir diğer önemli göstergesi de tutuklu ve hükümlü sayılarındaki değişimdir; bu değişkendeki 1998-2017 arasındaki artış grafikte (bkz. Şekil 3) görülebilir. 2017'de Türkiye'de toplam 232.340 hükümlü ve tutuklu vardır; bu sayı 1998'e göre yaklaşık 3,5 kat artmıştır.

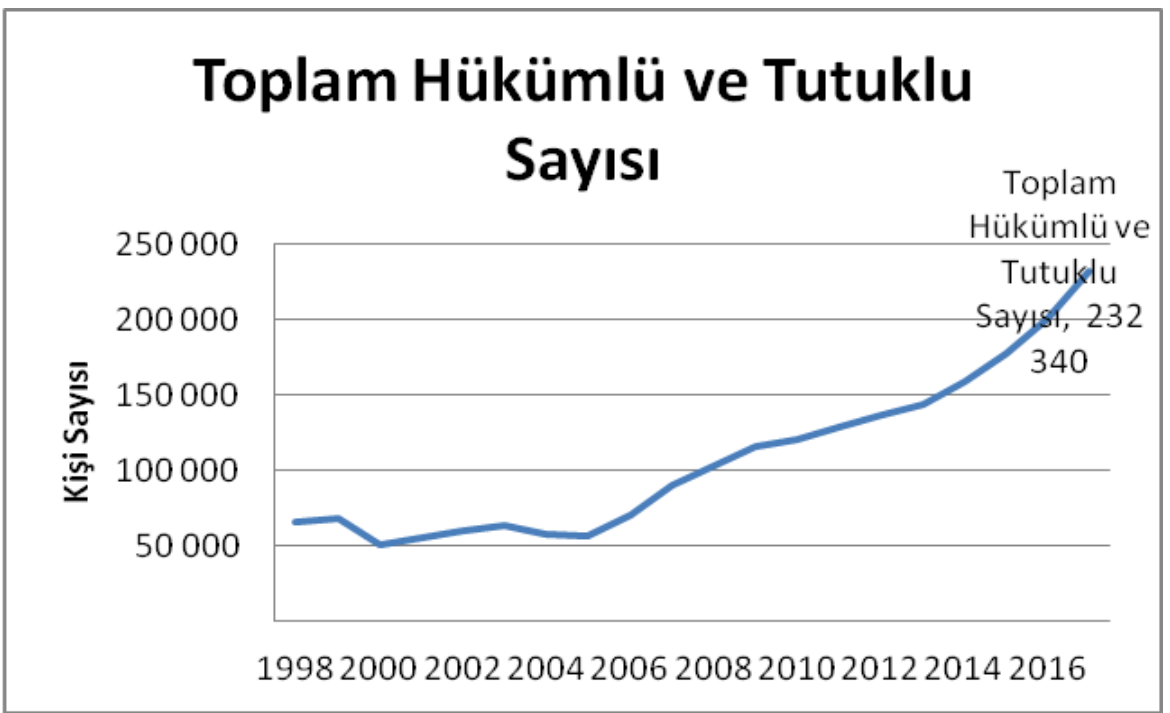

Şekil 3. 1998-2017 Yılları Arasında Hükümlü ve Tutuklu Sayısındaki Değişim (Kaynak: TÜiK'in “Hükümlü ve Tutuklu Sayısı” verisine göre hazırlanmıştır.)

Türkiye'de devletin özgürlükçü maskesini indirmesinin sonucunda dış göçler artmaktadır. Bu yalnızca gelecekleriyle ilgili umutsuzluğa düşen gençleri' ${ }^{6}$ değil (TÜİK, 2018), ekonomik, kültürel ve toplumsal sermayelerini sürdürebilme endişesine kapılan üst sınıfları ve onların toplumsal örgütlenmelerini de kapsar (bkz. NYT: Varlıklı ve Yetenekli Türkler Sürüler Halinde Ülkeyi Terk Ediyor, 2019). Bu aşamada devlet ve seçkin sınıflar arasındaki liberal uzlaşma bozulmuştur. Devlet kendi egemenleri arasındaki iç çatışmayı sonuçlandırmış, kendini bütün maddi ve simgesel gücüyle aşağıdakilerin ve yukarıdakilerin kendi öngördüğü

${ }^{6}$ Türkiye'yi etkileyen güncel bir sorun olan "beyin göçü" ile ilgili bir yazı dizisi için bkz. Aydoğan Çetin, 2019. 
biçimde birleştirilmesine vermiştir. Türkiye'deki yeni ekonomi ise, ne tam olarak Wacquant'ın sözünü ettiği modern kapitalizm, ne de onun neoliberal ideolojisidir. Modern öncesi geleneksel toplumun ekonomisi değilse ki işleyiş olarak "ahbap çavuş kapitalizmi" (Aykut ve Yıldırım, 2018) deyişinde dile getirildiği gibi onu zaman zaman andırdığı söylenebilir, merkezileşme eğilimi ile birlikte kapitalizmin ilkel dönemlerindeki vahşi kapitalizme yakınsar (Yıldızoğlu, 2018). Toplumsal ve ekonomik gelişmedeki bu gerileme liberal üst sınıfların ülkeden daha çok uzaklaşma ve sermayelerini başka coğrafyalarda güvenceye alma eğilimlerini arttırır.

\section{Sonuç}

Bu kısa çözümlemeden görülebileceği gibi Wacquant ve Bourdieu Türkiye'deki siyasal, ekonomik ve toplumsal alanların ve kentsel mekânın dönüşümü ile ilgili geniş ve dar ölçekli incelemelere dayanak oluşturacak uygun kavramsal çerçeveleri sunar. Yine de, bunun gibi belirli bir zamanda belirli bir coğrafyadaki gelişmeleri anlamak için Bourdieu'nün ve Wacquant'ın kavramlarına başvurma ve bunun ötesinde farklı coğrafyalardaki eş ya da farklı zamanlardaki gelişmeleri karşılaştırma girişimleri değerli olduğu kadar risklidir. Wacquant'ın Bourdieu'nün kavramsal çerçevesini kullanmakla ilgili uyarılarında olduğu gibi doğru yöntemleri benimsemek, araştırılan yerin özel bağlamını (örneğin, belki bu coğrafya için Wacquant'ın kentsel dönüşüm üçgeninde etnik köken yerine din değişkeni gelebilir) ve aynı zamanda, kavramlarına başvurulan araştırmacının araştırma ilkelerini dikkate almak önemlidir. Böyle önlemler ABD'ye özgü getto kavramını Fransız banliyösü ya da Türk gecekondusu için değiştirmeden kullanmak gibi hataları engeller. Diğer uçta ise, çokkültürlülük kuramında olduğu gibi bir akademik oryantalizm ya da akademinin aykırılık üretmesi yaklaşımı söz konusudur. Bununla birlikte Wacquant'ın Bourdieu'ye başvurarak sanayi-sonrası kentinin güvencesiz çalışanlarının ve karşısındaki farklı güç odaklarının karşılaştırmalı bir toplumbilimini üretme amacı günümüzde anlamlı bir çaba olmayı sürdürür. 


\section{Extended Abstract}

\section{Re-thinking Contemporary Turkey with Loïc Wacquant}

This article argues that Wacquant undertakes two duties in his researches. One of these duties is to explain and promote in academic research the correct usage of Bourdieu's conceptual framework. A trivial criticism to Wacquant in this regard is that he neglects that his own Bourdieu readings are also mediations, even though he provides explanatory analysis of Bourdieu by showing good and bad examples of applying Bourdieuan concepts. Wacquant's second duty is to follow Bourdieu methodologically in developing his own theories on the relationships among the penal state, race and social class, as well as on body, and urban ethnography. Under this duty, Wacquant's Centaur state as a two-faced state of neoliberalism emerged as a significant determinant in most of his work. This state was liberal at the top, and paternalist at the bottom. This paper summarizes first Wacquant's most representative work for these duties. Next, it discusses the applicability of the social conditions of the late twentieth century USA and France for Turkey. Finally, it investigates whether Bourdieu's concepts like bureaucratic field could guide an endeavour to understand the current sociopolitical context in Turkey. The paper interprets the recent power centralization as the domination of state's paternalism over its liberalism, and supports this argument with data.

Wacquant traced the political and economic roots of the hyperghettoization of poor U.S. neighbourhoods back to the developments after the World War II, such as labour market's divisions and spatial divisions, welfare state's erosions, and the resulting increase in the black belt's poverty and lack of support. According to Wacquant these changes in the urban regime brought about a decisive transformation, and even dissociation of the black American ghetto. The ghetto that had shown social and communal characteristics until the end of 1960s fragmented with the effect of deindustrialization, and it became a hyper-ghetto or an anti-ghetto. Wacquant underlined the two significant features of the 
post-1990 hyper-ghetto to be its decentralization or fragmentation and its centre's intensive corrosion. The emergence of the post-industrial precariat and the state's role in this development were observed in both the U.S. and European cities, and they resulted in the birth of a new poverty regime. Therefore, Wacquant argued that the government and its politics should be reclaimed urgently by any urban inquiry. Based on this analysis he developed his ideas on urban marginality, penality of the Centaur state, and ghettoization of prisons.

Wacquant also promoted the usage of Bourdieu's conceptual tools, and an understanding of the underlying research principles that he deemed invaluable for urban sociology. One of Bourdieu's research principles that had the influence of Leibniz and Durkheim emphasized the need to follow the reciprocal relationships among symbolic space, social space and physical space through a topological reasoning. The physical space equaled to a materialized social space, because social divisions and segregations reflected on it. Bourdieu's another research principle that was inspired by Cassier underlined the significance of symbolic structures in forming social dispositions and positions. In relation to that Wacquant referred to Bourdieu's often neglected concept of symbolic power. Accordingly, the symbolic categories that subjects used to comprehend the World were competing with each other. This competition influenced the city's physical and symbolic spaces, such as its buildings, activities, and place names.

Many examples of symbolic power conflicts over physical space could also be found in Turkey. It is possible to read the current sociopolitical context or the bureaucratic field in Turkey by applying Bourdieu's and Wacquant's concepts. The Bourdieu's state as a multiple structure, which gathers together material and symbolic power at a certain time in history, but which still has its internal conflicts is easily conceivable for the Turkish context. However, applying Wacquant's idea of the neoliberal Centaur state that is liberal at the top and punitive at the bottom to Turkey would be more troublesome. The reason is the growing power centralization at a single institution, causing a separation from the multiple structure of the modern bureaucratic field with autonomous institutions. This ongoing centralization tendency that Wacquant has not ignored in an interview could be interpreted as the paternalist (penal) state's domination over the (laissez-faire) liberal state in his words. Moreover, the Turkish governmental paternalism that usually benefits from social po- 
larization has a wider scope than its U.S. and European counterparts, as it could be similarly penal for all societal sections that do not legitimize its symbolic power regardless of who they are.

In Turkey outmigration grows as the state took off its liberal mask. This people's flight does not only concern the youth that lost their future hopes, but also the upper classes and their organizations that began to worry about the sustainability of their economic, cultural, and social capital that is, their social class positions and life styles. The liberal agreement between the state and the elite classes has been broken at this stage in Turkey. The state has ended the internal conflicts among the sovereign that Bourdieu gave more importance and it has devoted its full power to a consolidation of the top and the bottom according to its vision. The new economy in Turkey on the other hand is considered to be neither the modern capitalism that Wacquant speaks of nor its neoliberal ideology. It begins to resemble the vulgarity of the primitive capitalism along with the power's centralization. This regression in social and economic evolution of the society continues to deter the liberal upper classes with their growing tendency to secure their capital in other geographies.

As exemplified by this short analysis Wacquant and Bourdieu provide the pertinent conceptual frameworks as a basis for both macro- and micro-level investigations of the political, economic, social, and physical transformations of contemporary Turkey.

\section{Kaynakça/References}

Akçaoğlu, A. (2018). Zarifve Dinen Makbul: Muhafazakâr Üst-Orta Sinff Habitusu. İstanbul: İletişim Yayınları.

Aydoğan Çetin, D. (2019, 11 Ocak). Gidenler Anlatıyor [1]: Güvende Hissetmiyoruz. Birgün. https://www.birgun.net/haber-detay/gidenler-anlatiyor-guvendehissetmiyoruz.html adresinden erişildi.

Aydoğan Çetin, D. (2019, 12 Ocak). Gidenler anlatıyor [2]: Sosyal ve Ekonomik Kayg1 Duymadığımızda Dönmek İsteriz. Birgün. https://www.birgun.net/haberdetay/gidenler-anlatiyor-2-sosyal-ve-ekonomik-kaygi-duymadigimizdadonmek-isteriz.html adresinden erişildi.

Aydoğan Çetin, D. (2019, 13 Ocak). Gidenler anlatıyor [3]: Eğitim Sistemi Endişe Verici. Birgün. https://www.birgun.net/haber-detay/gidenler-anlatiyoregitim-sistemi-endise-verici.html adresinden erişildi. 
Aykut, E. ve Yıldırım, K. (2018, 9 Eylül). Neoliberalizm, “Ahbap-Çavuş Kapitalizmi” ve Türkiye. Birgün Pazar. https://www.birgun.net/haber-detay/neoliberalizmahbap-cavus-kapitalizmi-ve-turkiye-229835.html adresinden erişildi.

Bayhan, B. (2013, 13 Aralık). Hafıza mekânları. 8 Ocak 2019 tarihinde http://www.arkitera.com/haber/18781/hafiza-mekanlari adresinden erişildi.

Bourdieu, P. (2015). Dünyanın Sefaleti. (A. Sümer, Çev.). Ankara: Heretik Yayıncllık. (Özgün eserin yayın tarihi 1993).

Bozçalı, V. F., Aydın, S., Özden, C. (Söyleşenler) ve Wacquant, L. (Söyleşilen). (2007). Loic Wacquant ile söyleşi: Bourdieu ile devleti düşünmek. (A. Şaşmaz, Çev.). Birikim, 219. http://www.birikimdergisi.com/birikim-yazi/6076/loicwacquant-ile-soylesi-bourdieu-ile-devleti-dusunmek\#.XDRI9FwzaUk adresinden erişildi.

Erdoğan, E. (2018). Türkiye'de kutuplaşmanın boyutları araştırması [PowerPoint sunusu]. 8 Ocak 2019 tarihinde https://goc.bilgi.edu.tr/media/uploads/2018/02/05/bilgi-goc-merkezikutuplasmanin-boyutlari-2017-sunum.pdf adresinden erişildi.

Frégosi, V. ve Gonzalez, A. M. (Yapımcılar) ve Carles, P. (Yönetmen). (2001). La sociologie est un sport de combat [Sinema Filmi]. Fransa: C.P. Productions, V.F. Films Productions.

Harvey, D. (1989). From Managerialism to Entrepreneurialism: The Transformation in Urban Governance in Late Capitalism. Geografiska Annaler Series B-Human Geography, 71(1), 3-17. doi: 10.2307/490503

Kılıç, L. ve Kaya, İ. (2018, 1 Aralık). 'Kaymağı Hükümet Yiyor'. Cumhuriyet. http://www.cumhuriyet.com.tr/haber/siyaset/1156757/_Kaymagi_hukumet_y iyor_html adresinden erişildi.

NYT: Varlıklı ve Yetenekli Türkler Sürüler Halinde Ülkeyi Terk Ediyor. (2019, 3 Ocak). Cumhuriyet.

http://www.cumhuriyet.com.tr/haber/dunya/1189492/NYT_Varlikli_ve_yeten ekli_Turkler_suruler_halinde_ulkeyi_terk_ediyor.html adresinden erişildi.

Savage, M. (2012). The Lost Urban Sociology of Pierre Bourdieu. G. Bridge ve S. Watson (Der.), The New Blackwell Companion to the City içinde (ss. 511-520). West Sussex, İngiltere: Wiley-Blackwell.

Slater, T. (2006). The Eviction of Critical Perspectives from Gentrification Research. International Journal of Urban and Regional Research, 30(4), 737-757. doi: 10.1111/j.1468-2427.2006.00689.x

Şahin, U. (2017, 12 Kasım). AKM Elitlerin Değil, Halkındı! Birgün.

https://www.birgun.net/haber-detay/akm-elitlerin-degil-halkindi189770.html adresinden erişildi.

Şahin, U. (2019, 13 Ocak). Türkiye'deki Yardımlarda Politik İstismar Söz Konusu. Birgün. https://www.birgun.net/haber-detay/turkiyedeki-yardimlardapolitik-istismar-soz-konusu.html adresinden erişildi. 
T.C. Adalet Bakanlığı Strateji Geliştirme Başkanlığı. (2016). Yatırım projeleri listesi. 14 Ocak 2019 tarihinde http://www.sgb.adalet.gov.tr/ekler/butce/2016-yiliyatirim-toplulastirilmis-projeler-detay-listesi.pdf adresinden erişildi.

T.C. Adalet Bakanlığı Strateji Geliştirme Başkanlığı. (2017). Yatırım projeleri listesi. 14 Ocak 2019 tarihinde http://www.sgb.adalet.gov.tr/ekler/butce/2017-yiliyatirim-toplulastirilmis-projelerin-detay-tablosu-tumu.pdf adresinden erişildi.

T.C. Adalet Bakanlığı Strateji Geliştirme Başkanlığı. (2018a). 2017 yılı bakanlık faaliyet raporu. 14 Ocak 2019 tarihinde

https://www.adalet.gov.tr/Bakanlik/FaaliyetRaporu/pdf/rapor2017.pdf adresinden erişildi.

T.C. Adalet Bakanlığı Strateji Geliştirme Başkanlığı. (2018b). Yatırım projeleri listesi. 14 Ocak 2019 tarihinde http://www.sgb.adalet.gov.tr/ekler/butce/2018-yiliyatirim-toplulastirilmis-projelerin-detay-tablosu-tumu.pdf adresinden erişildi.

Toker, Ç. (2017, 20 Eylül). Cezaevi yaptırmak kolaylaşırken. Cumhuriyet. http://www.cumhuriyet.com.tr/koseyazisi/827394/Cezaevi_yaptirmak_kolayl asirken.html adresinden erişildi.

TÜİK. (2017). Hükümlü ve tutuklu sayısl, 1998-2017. 14 Ocak 2019 tarihinde http://tuik.gov.tr/UstMenu.do?metod=temelist adresinden erişildi.

TÜİK. (2018). Uluslararası göç istatistikleri, 2017 (Sayı: 30607). 14 Ocak 2019 tarihinde http://tuik.gov.tr/PreHaberBultenleri.do?id=30607 adresinden erişildi.

Wacquant, L. (2004). Following Pierre Bourdieu into The Field. Ethnography, 5(4), 387-414. doi: 10.1177/1466138104052259

Wacquant, L. (2008). Relocation Gentrification: The Working Class, Science and the State in Recent Urban Research. International Journal of Urban and Regional Research,31(1), 198-205. doi: 10.1111/j.1468-2427.2008.00774.x

Wacquant, L. (2014). Marginality, Ethnicity and Penality in the Neo-liberal City: An Analytic Cartography. Ethnic and Racial Studies, 37(10), 1687-1711. doi: 10.1080/01419870.2014.931991

Wacquant, L. (2015). Kent paryaları: Illeri marjinalliğin karşılaştırmalı sosyolojisi (2. bs.).

(M. Doğan, Çev.). İstanbul: Boğaziçi Üniversitesi Yayınevi. (Özgün eserin yayın tarihi 2008).

Wacquant, L. ve Akçaoğlu, A. (2017). Practice and Symbolic Power in Bourdieu: The View from Berkeley. Journal of Classical Sociology, 17(1), 55-69. doi: $10.1177 / 1468795 \times 16682145$

Wacquant, L. (2018a). Bourdieu comes to town: Pertinence, principles, applications. International Journal of Urban and Regional Research, 42(1), 90-105. doi:

$10.1111 / 1468-2427.12535$

Wacquant, L. (2018b, Mayıs). Bio. 5 Ocak 2019 tarihinde https://loicwacquant.org/background/ adresinden erişildi. 
Yıldızoğlu, E. (2018, 6 Ağustos). AKP ve Türkiye kapitalizmi. Cumhuriyet. http://www.cumhuriyet.com.tr/koseyazisi/1047092/AKP_ve_Turkiye_kapitali zmi.html adresinden erişildi.

Meriç Kırmızı 2017 Mart'ında Osaka Üniversitesi İnsan Bilimleri Fakültesi'nden doktora derecesini alıp, Osaka Kent Üniversitesi Kent Araştırmaları Merkezi'ndeki araştırma çalışmaların bitirdi. 2012 Nisan'ında MEXT Araştırma Bursu ile Japonya'ya gitmeden önce Orta Doğu Teknik Üniversitesi Sosyoloji Bölümü'nden yüksek lisans derecesini aldı. 2018 Ocak ayından beri Ondokuz Mayıs Üniversitesi FenEdebiyat Fakültesi Sosyoloji Bölümü'nde doktor öğretim üyesi olarak ders vermekte ve kent sosyolojisi alanında araştırmalarını sürdürmektedir.

Meric Kirmizi received her PhD degree in Human Sciences in the Graduate School of Human Sciences of Osaka University, and finished with her tasks as a research fellow at Urban Research Plaza in Osaka City University in March 2017. Before she arrived in Japan as a MEXT Research Student in April 2012, she received an M.S. degree in sociology from the Faculty of Arts and Sciences of Middle East Technical University. She has been teaching and doing research in the field of urban sociology as an assistant professor in sociology at the Faculty of Science and Letters of Ondokuz Mayis University since January 2018.

E-mail: merickirmizi@gmail.com 